\title{
Religion, Law, State, and COVID-19 in Vietnam
}

\author{
Nguyen Thi Phuong* \\ PhD Candidate, School of Law, City University of Hong Kong, Hong Kong \\ phuongmc20o3@yahoo.com
}

\begin{abstract}
The Vietnamese state has issued numerous measures to prevent the spread of COVID-19 in the country. This paper shows how the state used the law to manage religious activities for the purpose of public health during the epidemic. We argued that because of legal, institutional, and religious factors, the Vietnamese state was successful in establishing cooperation with religious organizations to implement measures restricting religious activities to limit the spread of the epidemic in the country.
\end{abstract}

\section{Keywords}

religion - state - COVID-19 - law - restrictions - regulations

\section{Introduction}

On July 21, 2020, Vietnam reported 396 coronavirus cases and no deaths, at a time when there were $14,880,261$ cases and 613,988 deaths worldwide. ${ }^{1}$ The international community has recognized that Vietnam is one of the countries that have effectively controlled the pandemic. ${ }^{2}$ The country has

* Master of Science (Asian Studies), Nanyang Technological University, Singapore; LLM, LLB, Vietnam National University-Hanoi.

1 COVID-19 trên thế giới [COVID-19 in the word], 2020, Vnexpress, 22 July 2020, Retrieved 22 July, 2020, https://vnexpress.net/covid-19/covid-19-the-gioi.

2 John Reed \& Pham Hai Chung, "Vietnam's Coronavirus offensive win praise for low-cost model" 2020, Financial Times, 24 March. Retrieved 30 April 2020, https://www.ft.com/ content/occ3c956-6cb2-11ea-89df-41bea05572ob. 
implemented many drastic measures to control the disease. ${ }^{3}$ Among others, these government measures strictly limited religious activities. How did the state restrict religious activities to prevent the spread of Covid-19? Why did religious authorities accept and support state restrictions? The present article addresses these questions. It argues that because of legal, institutional, and religious factors, the Vietnamese government was successful in establishing cooperation with religious organizations to implement measures restricting religious activities to limit the spread of the epidemic in the country.

\subsection{Religions in Vietnam}

Vietnam is a multi-religious country. Thousands of religious activities take place every year. ${ }^{4}$ Some scholars have discussed the tensions between state and religion in Vietnam, arguing that although Vietnam has made some progress in religious freedom since 1974, religious freedom, as articulated in international law, is far from being ideal. ${ }^{5}$ The current approach in Vietnam is said to allow space for religious worship but retain state control through registration and oversight. ${ }^{6}$ The Vietnamese state has accommodated a great diversity of religious traditions, practices, and beliefs. The state has been taking positive steps to improve freedom of religion and diversity of faith experiences. The government generally embraces the religious diversity of the country and publicly expresses support for religious freedom. ${ }^{7}$

Historically, the respect of the Vietnamese state for religious practise has been evident since the establishment of the state, in 1945. The provisional Government of the Democratic Republic of Vietnam, at its first meeting,

3 Vũ Hân, "Việt Nam đối xử bình đẳng với người nước ngoài trong đối phó dịch coviD-19" [Vietnam treats foreigners equally in dealing with COVID-19] 2020, Thanh Niên, 20 March. Retrieved 30 April 2020, https://thanhnien.vn/thoi-su/viet-nam-doi-xu-binh-dang-voi-nguoi -nuoc-ngoai-trong-doi-pho-dich-covid-19-1198739.html.

4 Hoang Van Nghia, "Religious Diversity and the Right to Freedom of Religion in Vietnam today", Academic Journal of Interdisciplinary Studies, MCSER Publishing, Rome-Italy. (2015).

5 Thomas J. Reede \& Mary Ann Glendon, "The struggle between government and religions", Report from Vietnam, America: The National Catholic Review, February 29, 2016. Retrieved 23 July 2020, https://web.archive.org/web/20160222224204/http://americamagazine.org/issue/ report-vietnam.

6 Report of a Home Office fact-finding mission to Vietnam, conducted between 23 February and 1 March 2019, 21 July. 2020, 25.

7 USCIRF, Annual Report 2019, Justice, 2019, Retrieved 23 July 2020, https://www.justice.gov/ eoir/page/file/1158891/download; Philip Taylor (Edited), Modernity and Re-enchantment Religion in Post-revolutionary Vietnam" (Institute of Southeast Asian Studies Singapore, 2007). Chung Van Hoang, New Religions and State's Response to Religious Diversification in Contemporary Vietnam -Tensions from the Reinvention of the Sacred (Springer International Publishing $1^{\text {st }}$ ed, 2019). 
proclaimed the principle of "freedom of belief and solidarity between religion and non-religion." ${ }^{8}$ At present, the Vietnamese government gives preference to religious diversity and seeks to treat all religions equally. ${ }^{9}$ The Law on Belief and Religion 2016 (replacing the Ordinance on Religion and Belief of 2004) contains new provisions, for example, shifting the regulatory process from an approval system to a less burdensome notification system, allowing such activities to move forward without explicit government approval. ${ }^{10}$ The law provides favorable conditions for individuals and organizations to implement religious activities that improve the harmony between the state and religions.

There are more than 24 million followers of religion in Vietnam, (about $27 \%$ of the Vietnamese population is categorized as religious believers). Religious groups have been a powerful presence in the country.11 In 2018, Vietnam recognized 16 religions, 43 religious organizations, 60 religious training establishments belonging to Buddhism, Catholicism, Protestantism, Hoa Hao Buddhism, and others. There are 29,977 worship facilities, 24.7 million followers, and 83,00o religious dignitaries or leaders. There are over 12 million Buddhists, 6.7 million Catholics, 2.5 million Cao Dai, 1.5 million Protestants, 80,000 Muslims, 1.5 million Pureland Buddhists, over 1.3 million Hoa Hao, 6o,0oo Four Debts of Gratitude adherents, 57,00o Hindus, 15,000 Strange Perfume from Precious Mountains followers, about 11,00o adherents of Minh Su, and about 1,00o adherents of Minh Ly. ${ }^{12}$ In 2010, Vietnam ranked third in the Religious Diversity Index (RDI), with a score of 7.7, following Singapore (9.0) and Taiwan $(8.2) \cdot{ }^{13}$

8 Nguyễn Khắc Huy, "Progress of Law on Religion in Vietnam from 1990 to the Present", Paper for the International conference on "Beginning the Conversation: Religion and Rule of Law in Southeast Asia”, 20 November 2014, http://vnctongiao.vass.gov.vn/noidung/hoing hihoithao/Lists/HTKHLienKetIGE/View_Detail.aspx?ItemID=13. Chung Van Hoang, "New Religions and State's Response to Religious Diversification in Contemporary Vietnam, Tensions from the Reinvention of the Sacred", Springer, ( $1^{\text {st }}$ ed., 2017), 154 .

10 DFAT Country Information report Vietnam, 21 June 2017, Australian Government, Department of Foreign Affairs and Trade, 21.

11 Report of a Home Office fact-finding mission to Vietnam, conducted between 23 February and $1^{\text {st }}$ March 2019, 9 September, 2019, 25.

12 "Nhà nước Việt Nam với việc đảm bảo quyền tự do tín ngưỡng, tôn giáo" [The Government of Vietnam and its assurance of freedom of religion and belief].

13 Religious Diversity Index (RDI) scores for countries, regions and the world based on the shares of eight major world religions (Buddhism, Christianity, Folk or traditional religions, Hinduism, Islam, Judaism, other religions considered as a group, and the religiously unaffiliated. The 10- point RDI is divided into four ranges: Very high (the top $5 \%$ of score, scores of 7.0 and higher), high (the next highest $15 \%$ of scores, which works out to $16 \%$ because of tie score, score from 5.3 to 6.9 ), moderate (the next $20 \%$ of scores, score from 3.1 to 5.2 ), and low (the bottom $59 \%$ of scores). 
This Article relies on material in Vietnamese, including the laws regulating religions and other legal documents issued during the CoviD-19 epidemic, as well as written announcements by leaders of the religious organizations.

\section{Restrictions and Response}

\subsection{State Restrictions of Religious Activities due to coVID-19}

In January 2020, the Vietnamese people were informed about the danger of COVID-19, which came from Wuhan, China. ${ }^{14}$ The first case was identified in Vietnam on January $23,2020 .{ }^{15}$ Since early January, however, the Vietnamese government had already undertaken measures to prevent the spread of the coronavirus. ${ }^{16}$

When the information about the two largest outbreaks in the world connected to religious practices, in Korea and Iran, reached Vietnam, the government recognized the need to restrict religious activities in the country. In early February, Prime Minister, Nguyễn Xuân Phúc, requested all festivals, including religious ones, those still in preparation or those already launched, to reduce their scale. ${ }^{17}$ On March 9, he called for drastic measures to protect public health. ${ }^{18}$ The Governemt stated that its top piority was lives and health of the

14 Kim Thoa, "Vũ Hán "một tháng phong thành": coviD-19 đã bùng phát như thế nào?" [Wuhan "a month of siege": How did covid-19 break out?] 2020. Tuổi Trẻ, 24 February. Retrieved 23 April 2020, https://tuoitre.vn/vu-han-mot-thang-phong-thanh-covid -19-da-bung-phat-nhu-the-nao-20200223093555976.html.

15 Lê Hiệp, "Toàn cảnh các ca nhiễm covid-19 tại Việt Nam tới 12.3" [Overview of covid-19 infections in Vietnam up to 12.3] 2020, Thanh Niên, 12 March. Retrieved 23 April 2020, https://thanhnien.vn/thoi-su/toan-canh-cac-ca-nhiem-covid-19-tai-viet-nam-toi -ngay-123-1194645.html

16 Vân Anh, "Phó Thủ tướng Vũ Đức Đam: Nhân dân là lực lượng quan trọng hành đầu trong phòng chống dịch Covid-19”, [Deputy Prime Minister Vu Duc Dam: The people are an important force leading in the prevention of the coviD-19 epidemic] 2020, Báo Quốc tế, 10 April. Retrieved 23 April 2020, https://baoquocte.vn/pho-thu-tuong-vu-duc-dam-nhan -dan-la-luc-luong-quan-trong-hang-dau-trong-phong-chong-dich-covid-19-113401.html

17 Thiên Điểu, "Đề nghị ngừng hoạt động tôn giáo đông người sau 2 ca CoviD-19 vì dự thánh lễ", [Proposal to cease mass religious activities after 2 cases of CoviD-19 because of attending Mass] 2020, Tuổi Trẻ, 18 March. Retrieved 30 April, https://tuoitre.vn/de-nghi-dung -hoat-dong-ton-giao-dong-nguoi-sau-2-ca-covid-19-vi-du-thanh-le-20200318153236624 .html.

18 Phó Thủ tướng Vũ Đức Đam chủ trì cuộc họp Ban Chỉ đạo phòng chống dịch bệnh covid-19 [Deputy Prime Minister Vu Duc Dam chaired the meeting of the Steering Committee for Disease Prevention and Control covid-19], 2020, Văn phòng Chính phủ, 25 March. Retrieved 30 April 2020, http://vpcp.chinhphu.vn/Home/Pho-Thu-tuong-Vu-Duc -Dam-chu-tri-cuoc-hop-BCD-phong-chong-dich-benh-COVID19/20203/27441.vgp. 
people. ${ }^{19}$ On March 27, 2020, the Prime Minister signed a directive including measures to prevent the spread of the virus. According to this directive, religious rituals were temporarily suspended, until April $15 .{ }^{20}$ On March 31, the Prime Minister issued decision No 16/CT-TTg concerning strict social distancing to be implemented nationwide on April 1 . The measure required all people to leave home only in case of emergencies, including the purchase of food or medicine, or going to work at factories and essential services. The measure banned public gatherings of more than two people. ${ }^{21}$ According to this measure, public religious practices were not considered essential activities, and gathering for these activities was not allowed.

To implement the above measure with regard to religious organizations in the country, the Vietnamese Government Committee for Religious Affairs (GCRA) took actions to guide all religions. On February 1, 2020, the GCRA issued an official dispatch 48/TG CP-VP, instructing leaders of religious organizations about preventing the spread of the coronavirus. ${ }^{22}$ The dispatch required leaders of religious organizations to increase awareness of the virus, stop organizing festivals, and restrict activities involving massive gatherings. The dispatch required leaders to inform their dignitaries, officials, and followers about COVID-19. ${ }^{23}$

On March 20, the GCRA issued another dispatch that required religious leaders to instruct their religious organizations not to organize mass activities;

19 Nghị quyết phiên họp Chính phủ thường kỳ tháng 3, [The Resolution of the Government's regular meeting in March] 2020, Báo Dân tộc, 10 April. Retrieved 24 April, http://baodan toc.vn/nghi-quyet-phien-hop-chinh-phu-thuong-ky-thang-3-1586434850664.html.

Chỉ thị số 15/CT-TTg ngày 27/3/2020, Về quyết liệt thực hiện đợt cao điểm phòng, chống dịch CoviD-19 [Directive 15 / CT-TTg of March 27, 2020, on drastically implementing the peak wave of prevention and control of the coviD-19 epidemic], http://vanban .chinhphu.vn/portal/page/portal/chinhphu/hethongvanban?class_id=2\&_page=1\& mode $=$ detail $\&$ document_id $=199574$.

21 Chỉ thị số 16/CT-TTg ngày 31/3/2020, Về thực hiện các biện pháp cấp bách phòng, chống dịch Covid-19 [Directive No. 16 / CT-TTg dated 31/3/2020, On the implementation of urgent measures to prevent and control CoviD-19], http://tulieuvankien.dangcongsan.vn/ Uploads/2020/3/7/31/Chi-thi-16.1.jpg.

22 Công văn số 48/TGCP-VP Về việc tăng cường phòng, chống lây lan dịch viêm đường hô hấp cấp do virus Corona gây ra. [Dispatch 48/TGCP-VP about strengthening prevention and control of the spread of corona virus].

23 Thanh Huyền, "Ban Tôn giáo Chính phủ: Chủ động và quyết liệt trong việc phòng, chống dịch Covid-19", [ Government Commission for Religious Affairs: Be proactive and drastic in prevention and control of COviD-19 epidemic] 2020, Ban Tôn giáo Chính phủ. Retrieved 24 April 2020, http://btgcp.gov.vn/Plus.aspx/vi/News/38/o/254/o/17018/Ban_Ton _giao_Chinh_phu_Chu_dong_va_quyet_liet_trong_viec_phong_chong_dich_covid_19. 
cease to organize annual religious congresses, conferences, and festivals; not to send people to participate in foreign religious activities; not to host dignitaries from countries or territories affected by the epidemic until it has been prevented or suppressed; to conduct religious activities online; and to avoid crowded places. The measure called for expanding the responsibility of dignitaries and their followers in preventing the spread of COVID-19; suspending the worship facilities that pose a risk of COVID-19, to prevent the spread of the epidemic among believers and communities. The measure also suggested that Vietnamese dignitaries and followers who were overseas should not return to Vietnam during the epidemic unless it was absolutely necessary. To return to Vietnam, religious followers who were overseas had to provide detailed information, including a medical declaration regarding the location of their stay and their travel route. Finally, the measure required the leaders of the religious organizations to support medical examinations and treatment facilities to help prevent the spread of COVID-19. ${ }^{24}$

On March 27, the GCRA sent a dispatch requesting religious organizations to cancel large religious gatherings from March 28 to April 15. All religious services and events of more than 20 people were to be suspended until April 15. Online religious services were encouraged. ${ }^{25}$ On April 6, the Chairman of GCRA signed a dispatch to the Archbishop President of the Catholic Bishops' Conference of Vietnam and to bishops of Catholic dioceses asking for stronger measures against COVID-19. He requested these organizations to suspend all religious gatherings and to hold religious services online instead.

To implement to the Prime Minister's directive concerning nationwide social distancing, on April 7, the GCRA also sent a dispatch to provincial religious committees to prevent large religious gatherings in the various localities. Provincial religious committees were required to regularly monitor the observance of the directive by local religious followers and organizations.

24 Công văn số 218/TGCP-VP ngày 20 tháng 3 Về việc tiếp tục đẩy mạnh phòng, chống dịch COVID-19 trong tình hình mới [Official Letter 218 / TGCP-VP dated 20 March on continuing to promote prevention and control of CoviD-19 epidemic in the new situation.], http://btgcp.gov.vn/Plus.aspx/vi/News/38/o/254/o/17005/Ban_Ton_giao_Chinh_phu _ban_hanh_cong_van_day_manh_phong_chong_dich_covid_19_trong_tinh_hinh_moi.

$25 \mathrm{NL}$, "Ban Tôn giáo Chính phủ đề nghị các tổ chức tôn giáo dừng ngay tất cả các hoạt động tập trung"[The Government Committee for Religious Affairs recommends that religious organizations stop all concentrated activities immediately] Ban Tôn giáo Chính phủ, 27 March. Retrieved 24 April 2020, http://btgcp.gov.vn/Plus.aspx/vi/News/38/o/254/o/17028/ Ban_Ton_giao_Chinh_phu_de_nghi_cac_to_chuc_ton_giao_dung_ngay_tat_ca_cac_hoat _dong_tap_trung. 
If local religious organizations and individuals violated the Prime Minister's directives and local regulations concerning preventive measures for controlling the epidemic, the violators were to be severely punished by law. ${ }^{26}$ This dispatch also stressed the role of religious leaders in preventing and controlling the spread of COVID-19. ${ }^{27}$

Since April 16, 2020, Vietnam has not reported any locally transmitted CoviD-19 cases. The social distancing was relaxed in some provinces. Nevertheless, to prevent the renewed eruption of CoviD-19, the Prime Minister enacted Directive 19 / Ст-Ttg on April 24, 2020 regarding the Continued Implementation of Measures to Prevent and Control COviD-19 in the New Situation. ${ }^{28}$ That measure continued to restrict religious activities.

To implement this directive, on the same day, the GCRA sent dispatch 271/TGCP-VP to leaders of religious organizations, asking that they continue implementing the measures aimed at preventing the recurrence of COVID-19 in the country. This dispatch stressed that all religious organizations were not invite dignitaries from overseas, especially from epidemic areas.

The above regulations restricted the religious practices of all religions in Vietnam. They affected the religious organizations, their followers, and believers. In Vietnam, some 8,500 religious activities are held every year. ${ }^{29}$ Limiting religious gatherings and activities posed a great challenge to the state. What was the response of the religious organizations to these regulations in Vietnam? Did they accept or oppose them? What was the attitude of the religious authorities? The next part considers these questions.

26 NL, "Sẽ xử lý nghiêm cá nhân, tổ chức tôn giáo vi phạm pháp luật và các Chỉ thị của Thủ tướng Chính phủ về phòng, chống CoviD” [Severely punish individuals and religious organizations that violate the law and the Prime Minister's Directive on the prevention and control of COviD] Ban Tôn giáo Chính phủ. Retrieved 25 April, 2020, http://btgcp.gov.vn/ Plus.aspx/vi/News/38/o/254/o/17047/Se_xu_ly_nghiem_ca_nhan_to_chuc_ton_giao_vi _pham_phap_luat_va_cac_Chi_thi_cua_Thu_tuong_Chinh_phu_ve.

27 NL, "Phát huy vai trò chức sắc đứng đầu các tôt chức tôn giáo trong thực hiện phòng chống covid." [Promote the leading dignitaries' role in religious organizations in the prevention of Covid.], Ban Tôn giáo Chính phủ. Retrieved 25 April 2020, http://btgcp.gov .vn/Plus.aspx/vi/News/38/0/254/0/17056/Phat_huy_vai_tro_chuc_sac_dung_dau_cac_to _chuc_ton_giao_trong_thuc_hien_phong_chong_covid.

28 Directive 19 / ст-Ttg Of The Prime Minister, April 24, 2020, On the continued implementation of measures to prevent and control CoviD-19 in the new situation.

29 Báo cáo quốc gia về thực hiện quyền con người ở Việt nam theo cơ chế kiểm định phổ cập (UPR) chu kỳ II" [Vietnam national report on the promotion and protection of human rights under the 2nd cycle universal periodic review"], Bộ Ngoại Giao Việt Nam. Retrieved 25 April http://www.mofahcm.gov.vn/vi/mofa/ctc_quocte/ptklk/nro40819162124/ ns131204084101. 


\subsection{Response of the Religious Organizations}

Religious organizations in the country took the state regulations seriously. They accepted and supported state measures to prevent and control the spread of COVID-19, and are considered important contributors to the fight against the COVID-19 epidemic. ${ }^{30}$ Authorities of all religious organizations sent out letters to ask their followers to strictly observe the epidemic prevention measures of the government. ${ }^{31}$ They issued dispatches to ask followers to raise awareness about preventive measures against the spread of COVID-19 epidemic; scale down religious services; limit the scale of large gatherings at places of worship; suspend catechism classes; and especially cooperate with the state against COVID-19..$^{32}$

30 Hương Diệp, "Các tôn giáo cùng chung tay đẩy lùi dịch covid-19" [Together, religions repelled the coviD-19 epidemic] 2020, Mặt trận Tổ Quốc, 12 March. Retrieved 26 April 2020, http://mattran.org.vn/dan-toc-ton-giao/cac-ton-giao-cung-chung-tay-day-lui-dich-cov id19-32707.html.

31 Ngọc Duyên, "Nhiều tổ chức tôn giáo tích cực ủng hộ cho công tác phòng, chống dịch Covid-19" [Many religious organizations actively support the prevention of the CoviD-19 epidemic] 2020, Ban tôn giáo Chính phủ. Retrieved 26 April 2020, http://btgcp .gov.vn/Plus.aspx/vi/News/38/o/282/o/17076/Nhieu_to_chuc_ton_giao_tich_cuc_ung_ho _cho_cong_tac_phong_chong_dich_COVID_19 NL, "Các tổ chức tôn giáo quán triệt thực hiện chỉ thị cách ly xã hội” [Religious organizations strictly observe the social isolation directive] 2020, Ban tôn giáo Chính phủ. Retrieved 26 April 2020, http:// btgcp.gov.vn/Plus.aspx/vi/News/38/0/248/o/17044/Cac_to_chuc_ton_giao_quan_triet _thuc_hien_chi_thi_cach_ly_xa_hoi.

32 1.Công văn số $071 / \mathrm{CV}-\mathrm{H} Đ$ TS của Giáo hội Phật giáo Việt Nam về việc thực hiện nghiêm Chỉ thị số 15/CT-TTg của Thủ tướng Chính phủ, chung tay cùng toàn xã hộ trong những ngày cao điểm chống dịch covid-19. [On 27 March, 2020, The Vietnam Buddhist Sangha's Executive Central Committee issued 071/CV-HDTs to implement the PM's Direction No 15/CT-TTg].

2. Thông báo ngày 02 tháng 02 năm 2020 của Hội đồng Giám mục Việt Nam Về việc phòng chống dịch bệnh viêm đường hô hấp do virus Corona [Notice dated February 2, 2020 of the Vietnamese Bishops' Conference on the prevention of respiratory diseases caused by Corona virus], https://hdgmvietnam.com/admin/upload/files/THONG\%20 BAO\%202.2.2020.pdf.

3. Thông tri ngày 05 tháng 022020 của Hội Thánh Cao đài toà thánh Tây Ninh Về Việc tăng cường các biện pháp phòng, chống dịch bệnh viêm đường hô hấp cấp do chủng mới của vi rút Corona gây ra [Announcement dated February 5, 2020, of Caodai Church in Tay Ninh on the strengthening of measures to prevent and combat cable-respiratory diseases caused by new strains of Corona virus], http://caodai.com.vn/vn/news-detail/tang-cuong-bien-phap-phong-chong-benh-do-vi-rut-corona-gay-ra.html.

Thông tri số 209 tháng 032020 của Hội Thánh Cao đài toà thánh Tây Ninh Về Việc Tiếp tục tham gia phòng, chống dịch bệnh viêm đường hô hấp cấp covid-19 [Announcement \#2 dated March 9, 2020, of Caodai Church in Tay Ninh on continuing to participate in the prevention and fight against acute respiratory infections coviD-19], http://caodai.com .vn/vn/news-detail/thong-tri-so-2-cua-hoi-thanh-ve-viec-tiep-tuc-tham-gia-phong -chong-dich-coronavirus-covid-19-1.html. 
These actions were intended to ensure that religious activities are carried out in a manner that shows responsibility toward the community. For example, the Archdiocese sent a dispatch to all parishioners requesting them to observe state regulations to prevent the spread of COVID-19. Followers were asked to remain in isolation for two weeks and not enter churches if they have CoviD-19 or related symptoms. They also halted all masses and religious services, including catechism classes and gatherings. ${ }^{33}$ All liturgical services were broadcast online, and parishioners could watch and follow the masses on the archdiocese's website. Leaders of religious organizations cooperated with local authorities and health officials to provide timely information to their followers. ${ }^{34}$

Religious organizations participated actively in preventing the spread of COVID-19. On April 18, 64 leaders and members of eight religious organizations participated in the blood donation program launched by Vietnam Fatherland Front's Hanoi. ${ }^{35}$ Religious organizations throughout the country raised around 16 billion VND (USD 688,394) to help the state prevent the spread of COVID-19.

In Vietnam, all covid-19 patients are treated for free, ${ }^{36}$ and the state provides many additional services free of charge. Therefore, the donations by religious organizations support the prevention efforts of the state. Following the

Thông tri số 3 ngày 24 tháng 032020 của Hội Thánh Cao đài toà thánh Tây Ninh Về Việc Tiếp tục đẩy mạnh phòng, chống dịch covid-19 trên địa bàn Tay Ninh quan”, dựa trên Văn thư số 451/SNV-TG của Sở Nội Vụ tỉnh Tây Ninh [Announcement \#3 of 24 dated March 2020 of Caodai Church in Tay Ninh on Continuing to promote the prevention and control of Covid-19 epidemic in Tay Ninh area", based on the Document 451 / SNV-TG of Department of Home Affairs of Tay Ninh province], http://caodai.com.vn/vn/news-detail/ thong-tri-so-3-cua-hoi-thanh-v-v-tiep-tuc-day-manh-phong-chong-dich-covid-19.html.

4. Thư kêu gọi Cầu nguyện và thông báo số 352/2020/TLH-VT ngày 27 tháng 3 năm 2020 của Tổng Liên Hội, Hội thánh tin lành Việt Nam [Letter calling for prayers and notices No. 352/2020 / TLH-VT dated March 27, 2020, of the Vietnam Federation of Protestant Churches], https://httlvn.org/thu-keu-goi-cau-nguyen-va-thong-bao-ve-dai-dich-covid-19.html.

$\mathrm{PH}$, "Ho Chi Minh archdiocese halts tenet classes to prevent COviD-19 epidemic", 2020, Religion, 17 March. Retrieved 26 April 2020, http://religion.vn/Plus.aspx/en/News/ 71/o/9028/0/12344/Ho_Chi_Minh_archdiocese_halts_tenet_classes_to_prevent_COV ID_19_epidemic.

34 PH, "Evangelical churches in Vietnam join hands in fighting against Covid-19", 2020, Religion, 17 March. Retrieved 26 April 2020, http://religion.vn/Plus.aspx/en/News/ 71/0/9028/o/12345/Evangelical_churches_in_Vietnam_join_hands_in_fighting_against_ COVID_19.

$35 \mathrm{PH}$, "Religious organizations continue supporting COVID-19 prevention", 2020, Religion, 15 April. Retrieved 26 April 2020, http://religion.vn/Plus.aspx/en/News/71/o/9028/o/12409/ Religious_organizations_continue_supporting_COVID_19_prevention.

36 L.A-D.Kim Thoa, "Việt Nam điều trị miễn phí covid-19, các nước ra sao?" [Vietnam free treatment CoviD-19, how are the countries?] 2020, Tuổi trẻ, 11 March. Retrieved 26 April, https://tuoitre.vn/viet-nam-mien-phi-dieu-tri-covid-19-cac-nuoc-ra-sao-2020 0311075720642.html. 
government measures, religious organizations and places of worship cancelled festivals, conferences, and activities for large crowds, including the Easter festival, Buddha's birthday festival, the Khmer New Year, the Congress of Cao Dai followers, annual meeting of the Baha'i Spiritual Council, and other events. ${ }^{37}$

Nevertheless, several religious activities continued to take place despite the efforts to control the spread of the CoviD-19. Some religious sectors even talked about the end of the world. ${ }^{38}$ Some priests at the district levels disobeyed state restrictions, did not follow the guidelines of the Vietnamese Catholic Bishops' Conference and of the Catholic dioceses, exposing the community to the risk of spreading the CoviD-19. For example, several priests in parishes under the Ha Tinh Diocese organized large gatherings of parishioners, attended by some 500 participants, on April 4 and $5,2020 .^{39}$

These acts disregarded government instructions, challenged the law, and affected the health and safety of the community. There were reasons for some of these infringements. In April, there were many important celebrations for Catholics, especially Easter, and believers wished to attend the rituals in the churches. The leader of the Ha Tinh Dioceses failed to manage religious activities effectively and to prevent the spread of CoviD-19. There was a general absence of social and civic responsibility demonstrated by both priests and parishioners. ${ }^{40}$

Another issue having to do with religious activities was that hundreds of people visited the closed Tay Ho Temple in Hanoi to worship the Mother Goddess on March 24, 2020 (the first day of the third lunar month). It is a Vietnamese custom to hold ceremonial meals in honor of ancestors and to go to the

37 Ban Tôn giáo Chính phủ, "Công văn số 218/TGCP-VP gửi lãnh đạo các tổ chức tôn giáo về việc tiếp tục đẩy mạnh phòng, chống dịch Covid-19 trong tình hình mới” [Official Letter 218 / TGCP-VP sent to the leaders of religious organizations about continuing to promote the prevention and control of the CoviD-19 epidemic in the new situation"] Bộ Nội Vụ, 21 March 2020. Retrieved 30 April 2020, https://moha.gov.vn/tin-tuc-su-kien/tin-hoat-dong -cua-bo-noi-vu/ban-ton-giao-chinh-phu-de-nghi-cac-ton-giao-42983.html.

38 Ban Tôn giáo Chính phủ cảnh báo hiện tượng lợi dụng dịch bệnh covid-19 để hoạt động trục lợi [The Government Committee for Religious Affairs warns of abusing the CoviD-19 epidemic for self-seeking activities], Sở Nội Vụ, 31 March 2020. Retrieved 26 April 2020, http://sonoivu.namdinh.gov.vn/qlnn-ve-ton-giao/ban-ton-giao-chinh-phu-canh-bao -hien-tuong-loi-dung-dich-benh-covid-19-de-hoat-dong-truc-loi-965.

39 PV, "Nhiều giáo xứ ở Hà Tĩnh vẫn tổ chức hành lễ đông người" [Many parishes in Ha Tinh still organize mass celebrations], Nhân Dân, 6 April, 2020. Retrieved 26 April 2020, https:// nhandan.com.vn/xahoi/tin-tuc/item/43942802.

40 Vũ Hợp Lân, "Không được nhân danh tôn giáo để vi phạm pháp luật" [Do not violate the law in the name of religion], Nhân dân, 8 April, 2020. Retrieved 12 May 2020, https://nhan dan.com.vn/chinhtri/tin-tuc-su-kien/item/43981102-khong-duoc-nhan-danh-ton-giao -de-vi-pham-phap-luat.html. 
pagoda or temple to pray for safety, health, good luck, prosperity, and happiness. It was for this reason that people ignored the regulation prohibiting religious activities to prevent the spread of COVID-19. ${ }^{41}$ Nevertheless, cooperation between the Chairman of the religious committee of the government, GCRA officials, the Vietnamese Catholic Bishops' Conference, the President of Bishops' Conference, and bishops of the dioceses was instrumental in preventing such events from reoccurring. The priests who violated the law were brought to justice. $^{42}$

Because no new cases have been recorded in the community from April 16 to date, religious activities have been resumed, although religious organizations exercise care in planning their activities. For example, on May 9, 2020, the Vietnam Buddhist Sangha (VBS) issued Official Letter 082/CV-HDTs on normal religious activities conducted in a way that helps control the spread of COVID-19. According to this letter, pagodas and other places of worship have been permitted to resume normal operation, but only for local Buddhist followers. Foreign visitors and Vietnamese living overseas, especially those returning from countries where the epidemic is rampant, are temporarily barred from attending. ${ }^{43}$

Cooperation between the state and religious organizations demonstrates the mutual responsibility they feel toward each other. This cooperation explains the success of the state in reducing the spread of the covid-19 epidemic in Vietnam.

\section{Factors Determining the Restrictions and the Response}

The success of the state in applying these restrictions to religious organizations throughout the country, and the positive response of the religious entities

41 Viet Tuan, Thanh Hue "Hundreds ignore covid-19 curfew, flock to Hanoi temple", Vnexpress, 25 March, 2020, Retrieved 23 July 2020, https://e.vnexpress.net/news/travel/places/ hundreds-ignore-covid-19-curfew-flock-to-hanoi-temple-4074589.html.

42 Ngô Tuấn-Xuân Lý, "Hà Tĩnh xử phạt các linh mục vi phạm quy định phòng, chống dịch" [Ha Tinh sanctioned priests who violated regulations on prevention and control of epidemics], Nhân Dân, 16 April, 2020. Retrieved 26 April 2020, https://nhandan.com.vn/ phapluat/thoi-su/item/44099802-ha-tinh-xu-phat-cac-linh-muc-vi-pham-quy-dinh -phong-chong-dich.html.

43 Công Văn Số 082/CV-HDTs Về Sinh Hoạt Tôn Giáo Bình Thường Trước Diễn Biến Mới Trong Phòng, Chống Đại Dịch covid-19 [The Official Letter 082/CV-HDTs On Normal Religious Activities in New Developments in the Prevention and Control of the CoviD-19 Pandemic]. 
are due primarily to three main types of factors: legal, institutional, and religious.

\subsection{Legal Factors}

The legal framework of the Vietnamese state has been regulating religious activities during the COVID-19. The state enacted regulations to restrict religious practices based on the Constitution and the the Law on Belief and Religion. The state applied these regulations to prevent the spread of the Covid-19 and to protect the public health. During the epidemic, the health of the community was a higher priority for the state than other goals. The regulations were formulated in a way that made sure not to infringe on the human rights of the people, and they adhered at all times to the ICCPR.

The Constitution of 2013 provides that "[e]veryone shall enjoy freedom of belief and religion; he or she can follow any religion or follow none." 44 But the Constitution stipulates that human rights (including the right to religious freedom) can be restricted by law for "national defense, national security, social order and security, social morality, and the health of the community." ${ }^{25}$ Article 6 of the Law on Belief and Religion, 2016, enforced since January 1, 2018, provides that everyone has the right to express his or her own religious beliefs; conduct religious worship rites; take part in religious or faith-based festivals; and learn and practice religious rules and laws. The law also stipulates, however, that religious activities can be prohibited to protect social order and safety, and the health and life of individuals, among others. ${ }^{46}$ Government restrictions on religious activities during the spread of Covid-19 in Vietnam were based on the Constitution and the laws of the country.

The constitutional and legal limitation of religious activities imposed in Vietnam for the purposes of public health adhere to international law. The ICCPR, to which Vietnam is a signatory, declares that "[e]veryone shall have the right to freedom of thought, conscience and religion. This right shall include freedom to have or adopt a religion or belief of his choice, and freedom, either individually or in community with others and public or private, to manifest his religion or belief in worship, observance, practice and teaching." ${ }^{\prime 7}$ This treaty also anticipates the limitation of this right: "Freedom to manifest one's religion or beliefs may be subject only to such limitations as are prescribed by

44 The Constitution of the Socialist Republic of Vietnam (2013), Article 24.

45 The Constitution of the Socialist Republic of Vietnam (2013), Article 14.

46 The Law on Belief and Religion of Vietnam (2016), Article 5.

47 The International Covenant on Civil and Political Rights (1966), Article 18. 
law and are necessary to protect public safety, order, health, or morals or the fundamental rights and freedoms of others." ${ }^{\text {48 }}$

\subsection{Institutional Factors}

Vietnam is a polity ruled by a single party: the Communist Party. The main ideology of the country is founded on Marxist-Leninist and Ho Chi Minh's thought. ${ }^{49}$ Vietnam aims to implement the "socialist rule of law." 50 The Constitution of 2013 declares that the source of authority lies in the people, and state authority belongs to the people. Power rests on the alliance between the working class, the peasantry, and the intelligentsia. ${ }^{51}$ This principle makes the religious organizations an important part of society. Vietnamese leaders have often stated that belief and religion can coexist with the process of building socialism in the country. ${ }^{52}$ In Vietnam, religious organizations are part of the "great unity," which is considered "a strategic source of power, a main motivation, and a factor crucial for the victory of the Vietnamese revolution."53 This is why all religious organizations were united in the fight against the pandemic, answering the call of the Vietnamese Party General Secretary and State President, Nguyen Phu Trong. He stressed that each agency, unit, organization, and locality must carry out the directions of the state carefully, closely coordinate efforts, and prioritize their resources, time, and effort in the fight against COVID-19. ${ }^{54}$

Another institutional factor involved in the restrictions imposed by the state on religious activities during the COVID-19 epidemic time is the administrative management of religion in the country. The system of management includes the government, the central state management agency, ministries, ministrylevel agencies, and people's committees at all levels. ${ }^{55}$ The Government Committee for Religious Affair proposed to the Prime Minister the regulations needed to prevent and control the spread of Covid-19. This explains why the

48 The International Covenant on Civil and Political Rights (1966), Article 18.

49 The Constitution of the Socialist Republic of Vietnam (2013), Article 4.

5o The Constitution of the Socialist Republic of Vietnam (2013), Article 2.

$51 \quad$ Ibid.

$5^{2}$ John Gillespie, "Human rights as a Larger Loyalty" The Evolution of Religious Freedom in Vietnam", Harvard Human Rights Journal/Vol.27.

53 Bui Ngoc Son, "Legal Regulation of Religion in Vietnam", in Jaclyn L.Neo, Arif A.Jamal, And Daniel P. S. Goh, Regulating Religion in Asia, Norms, Modes, and Challenges (2019), 161. "Tổng Bí Thư, Chủ tịch nước kêu gọi đoàn kết để chiến thắng dại dịch" [General Secretary, President calls for solidarity to win pandemic], Bộ Y Tế, 31 March 2020. Retrieved 26 April 2020, https://moh.gov.vn/tin-noi-bat/-/asset_publisher/3Yst7YhbkA5j/content/ tong-bi-thu-chu-tich-nuoc-keu-goi-oan-ket-e-chien-thang-ai-dich.

The Law on Belief and Religion of Vietnam (2016), Article 61. 
GCRA and the Prime Minister could coordinate the regulations concerned with the prevention of the pandemic. The GCRA enacted the regulations to apply the Prime Minister's directives, instructing all religious organizations to implement the restrictions. This consolidated the cooperation between the state and the religious organizations in their effort to reduce the effect of coviD-19.

\subsection{Religious Factors}

There are two main factors that caused religious organizations to cooperate with the state in the prevention and control the COVID-19: (a) the relationship between religious organizations and the state is harmonious and interdependent, and (b) most religious organizations have been operated from the central to local level to manage their branches' activities and to align with the state management. The capability of the Vietnamese state to manage the religious activities in the country to prevent and control the spread of CoviD-19 was based on regulations. The coordination between the state and the religious organizations was the main feature of the effort to regulate religion in Vietnam. It is the declared policy of the state that it is necessary to regulate religious organizations for the wellbeing of the community. The legal, institutional, and religious factors described account for the way in which the state regulates religious activities for the sake of public health. 